conferred by milk in swine species. Antibodies of the IgA class have a privileged function in the passive protection of piglets against enteritis caused by these enteric agents. The other humoral components (lactoferrin, lysozyme, lactoperoxydase) are still unknown. Recent works have described the different cellular subsets in milk, but their respective roles in the immune protection of young piglets have not been well established. Kinetics of lymphocyte subpopulations and plasma-cells was studied recently in the mammary gland of primiparous sows in relation to pregnancy and lactation. The determinism of the migration of lymphocytes towards the mammary tissue is unknown. Condition of lactogenic immunity seems to depend on several important parameters :

a) the properties of the enteric agent used as an antigen for immunization,

b) the conditions of administration of this antigen to the pregnant sow,

c) the physiological status of the sow at the time of antigen administration.

\title{
Identification of porcine epidemic diarrhoea (P.E.D.) in Brittany A clinical study
}

\author{
P. VANNIER, P. DEBOUCK
}

Ministère de l'Agriculture, Direction de la Qualité, Services vétérinaires, Station de Pathologie porcine, B.P. 9, 22440 Ploufragan

France

*Faculté de Médecine vétérinaire, Laboratoire de Virologie, Casinoplein 24, B 9000 Gand Belgique

Several cases of contagious gastro-enteritis were observed in Brittany during the winter 1981-1982. A study was made in 9 herds in which pigs suffered from digestive disorders. Faeces were collected and antibody kinetics studied in sick animals. No cases of transmissible gastroenteritis were found; contrary to that Porcine Epidemic Diarrhoea (P.E.D.) virus was identified and a seroconversion observed in nearly all the tested sera. A clinical study was performed in these herds. Diarrhoea appeared in unweaned piglets in almost 50 p. 100 of the herds ; the intensity of the observed clinical signs and the piglet mortality rate varied in the different herds according to some parameters which are difficult to evaluate. In all cases, most of the breeding animals and bacon pigs were affected. The mortality conditions of some bacon pigs were discussed.

\section{Porcine influenza in Brittany (Influenza $\mathrm{HSW}_{1} \mathrm{~N}_{1}$ )}

\author{
F. MADEC, J.M. GOURREAU *, C. KAISER *, A. VIGOUROUX **, \\ F. SALINGARDES **, P. PRIME** \\ Ministère de l'Agriculture, Direction de la Qualité, Services' vétérinaires, \\ Station de Pathologie porcine, B.P. 9, Ploufragan \\ * Ministère de l'Agriculture, Direction de la Qualité, \\ Laboratoire central de Recherches vétérinaires, 22, rue Pierre-Curie, B.P. 67, \\ 94703 Maisons-Alfort \\ ** Ministère de l'Agriculture, \\ Direction départementale des Services vétérinaires du Finistère, \\ 7, rue Anne-Robert-Jacques-Turgot, 29107 Quimper \\ France
}

An outbreak of influenza occurred in Brittany (France) in december 1981 and the disease widely spread throughout the country until september 1982. Most of the herds were affected and the clinical signs were similar to those described in other countries. Illness 
was more pronounced in bacon pigs $(50-100 \mathrm{~kg}$ weight $)$ than in sows or boars, but mortality was low. Most of these breeding animals did not get ill. Nevertheless, fever, anorexia and sometimes abortion were noticed. An influenza virus $\mathbf{H S W}_{1} \mathbf{N}_{1}$ was isolated in many herds and seroconversion was general $(95$ p. 100). Economic losses differed from one herd to another in relation with respiratory diseases especially pneumonia. Many epidemiological factors were involved in the spreading of influenza and their role was discussed. Clinical and serological studies in the herds 6 months post-infection showed the persistence of viral activity in some of them. This situation is being investigated.

\title{
Urinary disorders in sow herds : diagnosis, consequences, environmental and physiological factors
}

\author{
F. MADEC, Françoise DAVID * \\ Ministère de l'Agriculture, Direction de la Qualité, Services vétérinaires \\ * Station de Pathologie porcine, B.P. 9, 22440 Ploufragan \\ France
}

Three studies were made (Brittany, France) on urinary disorders in sows detected in slaughter houses, in experimental production units and in conventional herds. Nitrites were found in 17 p. 100 of them. Cytobacteriological controls showed the presence of bacteria in $36 \mathrm{p}$. 100 of urines, but acute bacteriuria $\left(10^{6}\right.$ germs $\left./ \mathrm{ml}\right)$ was only found in $13 \mathrm{p} .100$ of the sows. It was more frequent in sows than in gilts. Most bacteria were of faecal origin with facultative pathogenic properties. A diagnosis scheme is suggested comparing the different methods of detection of urinary disorders. Furthermore, comparison of the environmental conditions in a hundred herds allowed to determine the main factors responsible for urinary infection : water intake, hygiene, constipation and sedentariness.

\section{Health control of breeding herds Role of the laboratory of pig pathology}

\author{
M. REYBAUD, J.C. BUARD *, Marylène KOBISCH **, J.P. TILLON ** \\ Coopérative Agricole de la Mayenne (C.A.M.), \\ 89, rue de Magenta, B.P. 731, 53002 Laval Cedex \\ *Vétérinaire-conseil à la C.A.M. \\ ** Ministère de l'Agriculture, Direction de la Qualité, Services vétérinaires, \\ Station de Pathologie porcine, Les Croix, 22440 Ploufragan
}

France

During the last twelve years a steady concentration of pig production units was observed in France (in the West and in a restricted number of farms) as well as an intensification and development of selection shemes and exchanges of breeding animals.

Health control programmes and methods for decision of breeding animal diffusion were suggested by several authors (J. Forest \& A. MAllite, 1979; P. VANNiER, M. Kobisch \& J.P. Tillon, 1980).

Health control programmes of both selection and multiplier herds applied since 1975 are reported here.

In the present article, we only mention the control or respiratory diseases. Using two examples we show the role of the laboratory in the decision of diffusion or no diffusion.

The following data were collected in herds A and B : clinical observations, slaughter examinations (snout sections, lungs), results of controls in 10-week-old piglets performed 